\title{
Allocation of Macronutrients in Roots, Sheaths, and Leaves Determines Salt Tolerance in Rice
}

\author{
Thieu Thi Phong Thu ${ }^{1,2^{*}}$, Yasui Hideshi' ${ }^{3}$, Yamakawa Takeo ${ }^{4}$ \\ ${ }^{1}$ Plant Nutrition Laboratory, Graduate School of Bioresource and Bioenvironmental Sciences, Faculty of Agriculture, Kyushu \\ University, Fukuoka, Japan \\ ${ }^{2}$ Department of Cultivation Science, Faculty of Agronomy, Vietnam National University of Agriculture, Ha Noi, Vietnam \\ ${ }^{3}$ Plant Breeding Laboratory, Faculty of Agriculture, Kyushu University, Fukuoka, Japan \\ ${ }^{4}$ Plant Nutrition Laboratory, Faculty of Agriculture, Kyushu University, Fukuoka, Japan \\ Email:*phongthu_nha84@yahoo.com
}

How to cite this paper: Thu, T.T.P., Hideshi, Y. and Takeo, Y. (2018) Allocation of Macronutrients in Roots, Sheaths, and Leaves Determines Salt Tolerance in Rice. American Journal of Plant Sciences, 9, 1051-1069. https://doi.org/10.4236/ajps.2018.95081

Received: March 22, 2018

Accepted: April 17, 2018

Published: April 20, 2018

Copyright (c) 2018 by authors and ScientificResearch Publishing Inc. This work is licensed under the Creative Commons Attribution International License (CC BY 4.0).

http://creativecommons.org/licenses/by/4.0/

\begin{abstract}
To determine useful parameters for salt tolerance in rice and selection of salt-tolerant varieties, their macronutrient contents in roots, sheaths, and leaves were evaluated under salt stress condition. A hydroponic experiment was conducted to evaluate 29 rice varieties for salt tolerance. The salt stress treatment included an artificial seawater solution (electrical conductivity of 12 $\mathrm{dS} \cdot \mathrm{m}^{-1}$ ). After a 2 -week period of salt stress, standard evaluation scores (SES) of visual injuries for salt stress were assessed. In addition, we measured the contents of $\mathrm{N}, \mathrm{P}, \mathrm{K}, \mathrm{Na}, \mathrm{Mg}$, and $\mathrm{Ca}$ in roots, sheaths, and leaves. The results showed that differences in macronutrients in the different plant tissues correlated with rice tolerance to the salt stress condition. Under the control treatment, salt-tolerant varieties exhibited low $\mathrm{K}$ content in root. Under the salt stress treatment, the salt-tolerant varieties exhibited low SES, high $\mathrm{N}$ content in leaves and sheaths, low $\mathrm{Na}$ content in leaves and sheaths, low $\mathrm{Mg}$ content in leaves and sheaths, and low Ca content in sheaths. The salt-tolerant varieties also exhibited high salt stress treatment/control treatment (ST/CT) ratios for dry matter in sheaths, $\mathrm{N}$ content in leaves and sheaths, and $\mathrm{K}$ content in sheaths, and low $\mathrm{Na} / \mathrm{K}$ ratios in leaves and sheaths. Therefore, these parameters might be useful to understand salt tolerance in rice.
\end{abstract}

\section{Keywords}

Salt Tolerance, Rice, Macronutrient Content

\section{Introduction}

Globally, many high-output rice cultivation areas are located in coastal areas, 
where soil salinization has become a large problem causing many negative effects on rice growth. Soil salinization occurs frequently in arid and semiarid regions; however, it is also widespread in humid regions such as South and Southeast Asia [1], where rice is a staple food crop [2]. The salinity threshold for rice plants is $3 \mathrm{dS} \cdot \mathrm{m}^{-1} \mathrm{EC}$ (electrical conductivity). Above this threshold, a $12 \%$ reduction in rice yield occurs if there is a $1 \mathrm{dS} \cdot \mathrm{m}^{-1} \mathrm{EC}$ increase in salinity [3]. Rice seedlings die at a salt level corresponding to $10 \mathrm{dS} \cdot \mathrm{m}^{-1}$ [4], and yield loss can be as high as $90 \%$ if the level reaches $3.5 \mathrm{dS} \cdot \mathrm{m}^{-1}$ during the reproductive stage [5]. Moreover, the global population is predicted to reach 9 billion people by 2050 . This global population increase is expected to increase the need for agricultural production in marginal saline lands [6]. Global food production will need to increase by approximately $50 \%$ by 2050 to accommodate population growth [7] [8].

Scientists around the world have been attempted to develop new salt-tolerant rice cultivars by genetic methods. Evaluation of variation of genetic sources for salt tolerance in rice is the first step; then, identification of molecular markers associated with salt stress tolerance genes or QTL conferred tolerance to salt stress conditions for their use in marker-assisted breeding programs; finally, discovery of genes regulating salt tolerance and development of cultivars harboring that salt-tolerance genes [9] [10]. To implement these steps of developing salt-tolerant varieties, it is necessary to establish an effective screening method for salt tolerance that allows accurate identification of salt tolerance parameters useful for analysis at the molecular level.

Sodium chloride $(\mathrm{NaCl})$ salt has widely been added to hydroponic systems for use as a screening method for salt tolerance in rice. However, all soils contain a mixture of soluble salts. The most common cations associated with soil salinity are $\mathrm{Ca}^{2+}, \mathrm{Mg}^{2+}$, and $\mathrm{Na}^{+}$[11]. Salt accumulation in arable soils is derived mainly from irrigation water that contains some amount of $\mathrm{NaCl}$ from seawater [12] [13]. In addition to irrigation, seawater incursion into rivers and aquifers in coastal areas can be a serious source of salinization [14]. Few studies have investigated salt stress following exposure to ionic components similar to those in seawater. In previous research, many salt-tolerant traits in rice have been evaluated by examining shoots and roots, such as by determining $\mathrm{Na}$ and $\mathrm{K}$ contents and the $\mathrm{Na} / \mathrm{K}$ ratio. However, the mineral contents in leaf blade, leaf sheath, and root of rice seedlings differed greatly among varieties with different salt tolerances [15]. In this study, rice seedlings were exposed to artificial seawater (ASW) to evaluate the effects of salt stress on different plant tissues including leaf blade, sheath, and root based on the parameters of growth and macronutrient contents.

\section{Materials and methods}

\subsection{Plant Materials}

A set of 29 rice varieties (24 from the Kyushu University Cultivated Rice Collec- 
tion (KCR), four Japanese varieties, and one Vietnamese variety) were screened for salt tolerance from April 14 to May 16, 2016, at a greenhouse at Kyushu University, Hakozaki, Fukuoka, Japan $\left(33^{\circ} 37^{\prime} \mathrm{N}, 130^{\circ} 25^{\prime} \mathrm{E}\right)$. Average temperature at Fukuoka in April and May in 2016 were $16.8^{\circ} \mathrm{C}$ and $20.8^{\circ} \mathrm{C}$, respectively [16].

\subsection{Plant Growth Conditions and Screening Procedure}

One germinated seed was planted in commercial seedbed soil (Kokuryu Baido, Seisin Sangyo Co., Kitakyushu, Japan) in a seedbed shell and kept in a tray with tap water. The seedbed shell has 16 rows with 8 holes each. One row could be used for one variety test entry. Sizes of seedbed shell are $59 \mathrm{~cm}$ length and $30 \mathrm{~cm}$ width. Dimensions of tray are $60 \mathrm{~cm}$ length, $37 \mathrm{~cm}$ width and $7 \mathrm{~cm}$ height. After $1^{\text {st }}$ week, shells with seedling were transferred to larger box with Yoshida solution. Dimensions of box are $57 \mathrm{~cm}$ length, $32 \mathrm{~cm}$ width and $18 \mathrm{~cm}$ height. This box was then used until the end of experiment. The culture solution needed per box is about $25 \mathrm{~L}$.

Seedlings grew uniformly for 1 week in tap water and for 1 week in Yoshida (Y) solution [17]. The concentration of macronutrients of $\mathrm{N}, \mathrm{P}, \mathrm{K}, \mathrm{Ca}, \mathrm{Mg}$ are $40,10,40,40,40 \mathrm{ppm}$, respectively. The concentration of micronutrients of $\mathrm{Mn}$, $\mathrm{Mo}, \mathrm{Zn}, \mathrm{B}, \mathrm{Cu}$, Fe were $0.50,0.05,0.01,0.20,0.01,2.00 \mathrm{ppm}$, respectively. Y solution was used for rice cultivation in the control and as the basic solution in the salt stress treatment. In the control treatment, Y solution was used continuously throughout the experiment. In the salt treatment, seedlings were grown for a subsequent 2 weeks in a $12 \mathrm{dS} \cdot \mathrm{m}^{-1}$ EC solution ASW-Y solution. The ASW-Y solution was made by adding some chemicals to Yoshida solution to produce solution that is the same as artificial sea water condition. Concentration of $\mathrm{NaCl}$, $\mathrm{Na}_{2} \mathrm{SO}_{4}, \mathrm{MgCl}_{2}$, and $\mathrm{CaCl}_{2}$ in $12 \mathrm{dS} \cdot \mathrm{m}^{-1}$ electrical contivity ASW-Y solution were $87.5,5.8,11.2$, and $2.2 \mathrm{mM}$, respectively.

The solution was changed twice each week. The $\mathrm{pH}$ of the hydroponic solution was measured by $\mathrm{pH}$ meter ( $\mathrm{pH}$ meter HM-10P, DKK-TOA Corporation, Tokyo, Japan) and adjusted to 5.5 - 6.0. The EC of the solution was monitored using a handheld EC meter (Model CM-31P, DKK-TOA Corporation, Tokyo, Japan) to ensure that EC was maintained at $12 \mathrm{dS} \cdot \mathrm{m}^{-1}$.

\subsection{Evaluating Salt Tolerance and Determining Mineral Contents}

A standard evaluation score (SES) of visual injury under a 2-week period of the salt stress condition of $12 \mathrm{dS} \cdot \mathrm{m}^{-1}$ EC were assessed by the method described by [18]. The score 1 to 3 were given when the rice seedlings showed nearly normal growth compared to the non-treatment. The score 3 to 5 were given when the leaf tips or a few leaves of rice were whitish and rolled. The score 7 to 9 were given when the seedlings showed complete cessation of growth, their leaves were dried and some of them died. Seedling samples were cut into roots and shoots. After oven drying at $70^{\circ} \mathrm{C}$ for $24 \mathrm{~h}$, the shoots were divided into sheaths and leaves. Then, dry matter amounts were determined for the roots, sheaths, and 
leaves. Dry samples were milled into powder using a sample mill (TI-100, Heiko Seisakusho, Ltd., Tokyo, Japan). The macronutrient contents of roots, sheaths, and leaves were analyzed using an $\mathrm{H}_{2} \mathrm{SO}_{4}-\mathrm{H}_{2} \mathrm{O}_{2}$ digestion method [19], which was followed by analysis of total nitrogen (N) by the indophenol method [20], total phosphorus $(\mathrm{P})$ by the ascorbic acid method [21], and potassium (K), sodium $(\mathrm{Na})$, magnesium $(\mathrm{Mg})$, and calcium $(\mathrm{Ca})$ by atomic absorption spectrophotometry (Z5300 spectrophotometer, Hitachi, Tokyo, Japan).

\subsection{Statistical Analysis}

Analysis of variance was used to test for statistical significance of differences, followed by Tukey's HSD test; both were conducted using STATISTIX 8 (Analytical Software, Tallahassee, FL, USA). The correlations among parameters were investigated using correlation and regression analysis in Excel (Office Professional Plus 2016, Microsoft, Redmond, WA, USA).

\section{Results}

\subsection{Variation in Salt Tolerance in Rice}

The 29 genotypes of rice vary in the response to salt stress condition. The SES under the salt stress treatment is shown in Table 1. These scores ranged from 3.75 to 8.75. The SES score of KCR 136, Khao Kap Xang, was lowest (3.75), while the SES score of Khang Dang18 was highest (8.75). The 29 genotypes were divided into three groups: salt-tolerant group (STG), moderately salt-tolerant

Table 1.Standard evaluation score (SES) of the 29 rice varieties under the salt stress condition of $12 \mathrm{dS} \cdot \mathrm{m}^{-1} \mathrm{EC}$.

\begin{tabular}{|c|c|c|c|c|c|c|c|}
\hline CODE & Cultivar Name & SES & Group & CODE & Cultivar Name & SES & Group \\
\hline KCR136 & Khao kap xang & 3.75 & STG & KCR119 & Kitrana 508 & 7.25 & SSG \\
\hline KCR67 & Eh-ia-chiu & 4.00 & STG & & Sensho & 7.38 & SSG \\
\hline KCR219 & De abril & 4.90 & STG & KCR157 & IR29 & 7.50 & SSG \\
\hline KCR198 & Nep hoa vang & 5.38 & MSTG & KCR19 & Ta-poo-choz & 7.63 & SSG \\
\hline KCR208 & Trembese & 5.50 & MSTG & KCR53 & Malagkit pirurutong & 7.63 & SSG \\
\hline KCR20 & Short grain & 5.88 & MSTG & KCR79 & Dhola aman (Lowland aman) & 7.63 & SSG \\
\hline KCR48 & Kalukantha & 6.00 & MSTG & KCR193 & IR42 & 7.63 & SSG \\
\hline KCR12 & Carolina gold & 6.13 & MSTG & KCR60 & Som cau $70 \mathrm{~A}$ & 7.75 & SSG \\
\hline KCR91 & TD 2 & 6.13 & MSTG & & Genkitsukushi & 7.75 & SSG \\
\hline KCR31 & Makalioka34 & 6.38 & MSTG & KCR233 & IR54 & 8.00 & SSG \\
\hline KCR104 & Vary vato 462 & 6.50 & MSTG & & Koshihikari & 8.38 & SSG \\
\hline KCR108 & Avo 742 & 6.50 & MSTG & KCR246 & Tumo-tumo & 8.50 & SSG \\
\hline KCR149 & Kaw luyoeng & 6.75 & MSTG & & Nipponbare & 8.63 & SSG \\
\hline KCR124 & Lac 23 & 6.88 & MSTG & & Khang dan 18 (KD18) & 8.75 & SSG \\
\hline KCR225 & Basmati 217 & 6.88 & MSTG & & & & \\
\hline
\end{tabular}

EC, electrical conductivity; STG, salt-tolerant group; MSTG, moderately salt-tolerant group; SSG, salt-susceptible group. 
group (MSTG), and salt-susceptible group (SSG). The salt-tolerant group included salt-tolerant varieties with SES from 3 to lower than 5 . The moderately salt-tolerant group included moderately salt-tolerant varieties with SES from 5 to lower than 7. The salt-susceptible group included salt-susceptible varieties with SES from 7 to lower than 9. There was no highly salt-tolerant variety among 29 varieties. Only three cultivars, KCR 136, KCR 67 (Eh-Ia-Chiu) and KCR 219 (De Abril) were classified to STG, 12 for MSTG, and the remaining 14 for SSG.

\subsection{Effect of Salt Stress on N and P Contents of Roots, Sheaths, and Leaves}

We measured the $\mathrm{N}$ and $\mathrm{P}$ contents in roots, sheaths, and leaves for all 29 varieties (Table 2). The means calculated for each salt tolerance group are shown in Figure 1. The STG had the lowest $\mathrm{N}$ content in sheaths and leaves under the control condition, but, it had the highest $\mathrm{N}$ content under the salt stress condition. The correlation between SES scores and N content was high. The Pearson
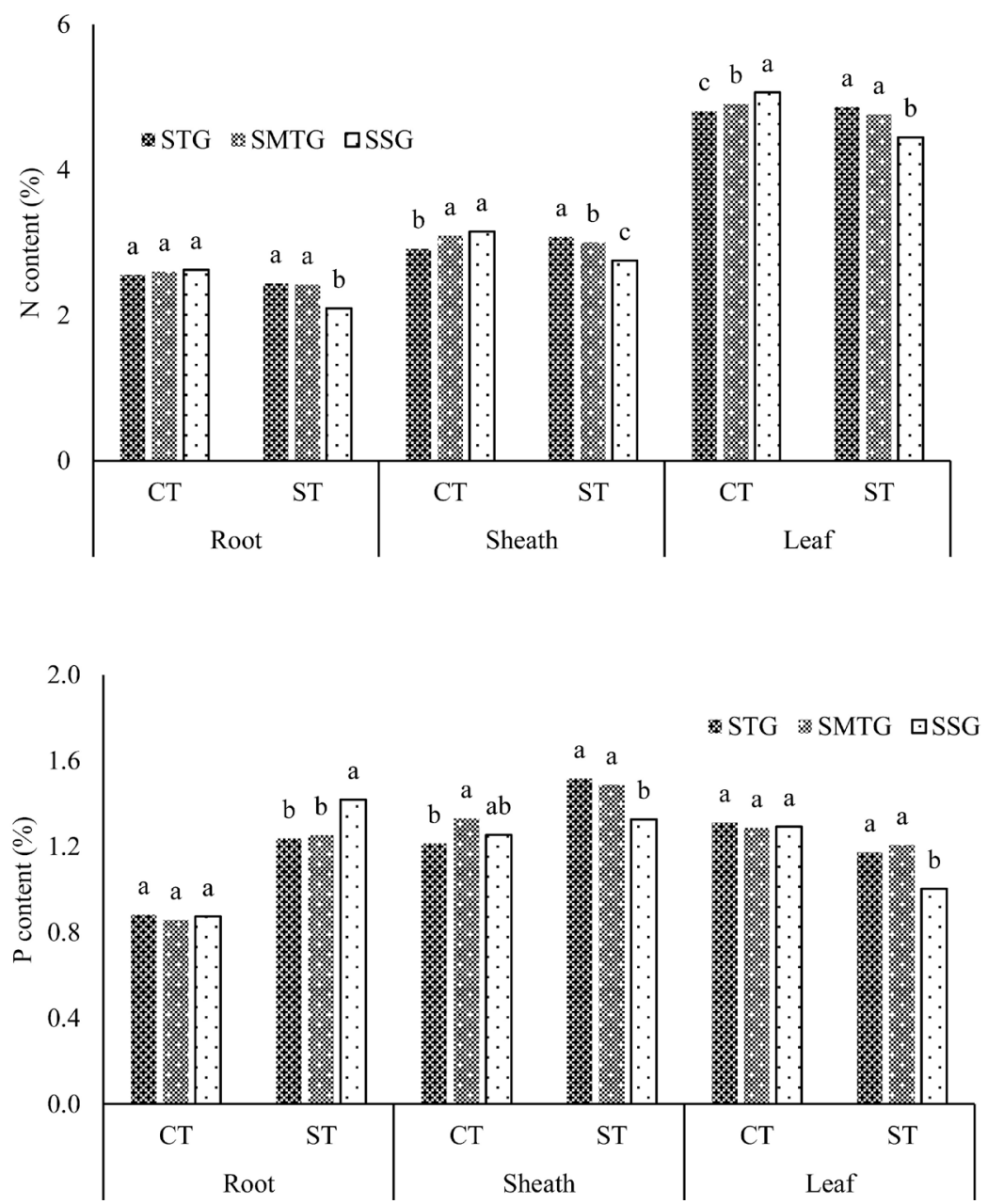

CT, control treatment; ST, salt treatment; STG, salt-tolerant group; MSTG, moderately salt-tolerant group; SSG, salt-susceptible group; the histograms in the same parameter with the same letter are not significantly different by Tukey HSD test $(P<0.05)$.

Figure 1. N and P contents of roots, sheaths, and leaves in the three salt tolerance groups. 
correlation index (PCI) values between SES scores and $\mathrm{N}$ content under the salt stress condition in roots, sheaths, and leaves were $-0.61,-0.43,-0.67$, respectively (Table S1). P content was not clearly different among the three groups. The ST/CT ratios for $\mathrm{N}$ and $\mathrm{P}$ content in roots, sheaths, and leaves among the three salt tolerance groups were shown in Figure 2. The STG showed the highest $\mathrm{ST} / \mathrm{CT}$ ratios for the $\mathrm{N}$ content of roots, sheaths, and leaves, followed by the MSTG and SSG. The STG also displayed the highest ST/CT ratio for the P content of sheaths, but not for roots or leaves.

\subsection{Single Regression Analysis between SES and ST/CT Ratios of N Content, Na/K Ratios and Na Contents in Roots, Sheaths, and Leaves in THE Salt-Stress Treatment (Figure 3, Table 2)}

For roots, sheaths, and leaves, the ST/CT values for $\mathrm{N}$ content were highly correlated with SES scores $\left(\mathrm{R}^{2}: 0.5061,0.5321\right.$, and 0.6692 , respectively). The ST/CT values for $\mathrm{Na}$ content were highly correlated with SES scores in sheaths and leaves $\left(R^{2}: 0.6961\right.$ and 0.7087 , respectively), and the $\mathrm{Na} / \mathrm{K}$ ratios were also highly correlated in sheaths and leaves $\left(\mathrm{R}^{2}: 0.5003\right.$ and 0.5878 , respectively). The results of the single regression analysis revealed that KCR 136 and KCR 67 could be distinguished from the other varieties by $\mathrm{N}$ content in leaves, $\mathrm{Na}$ content in sheaths
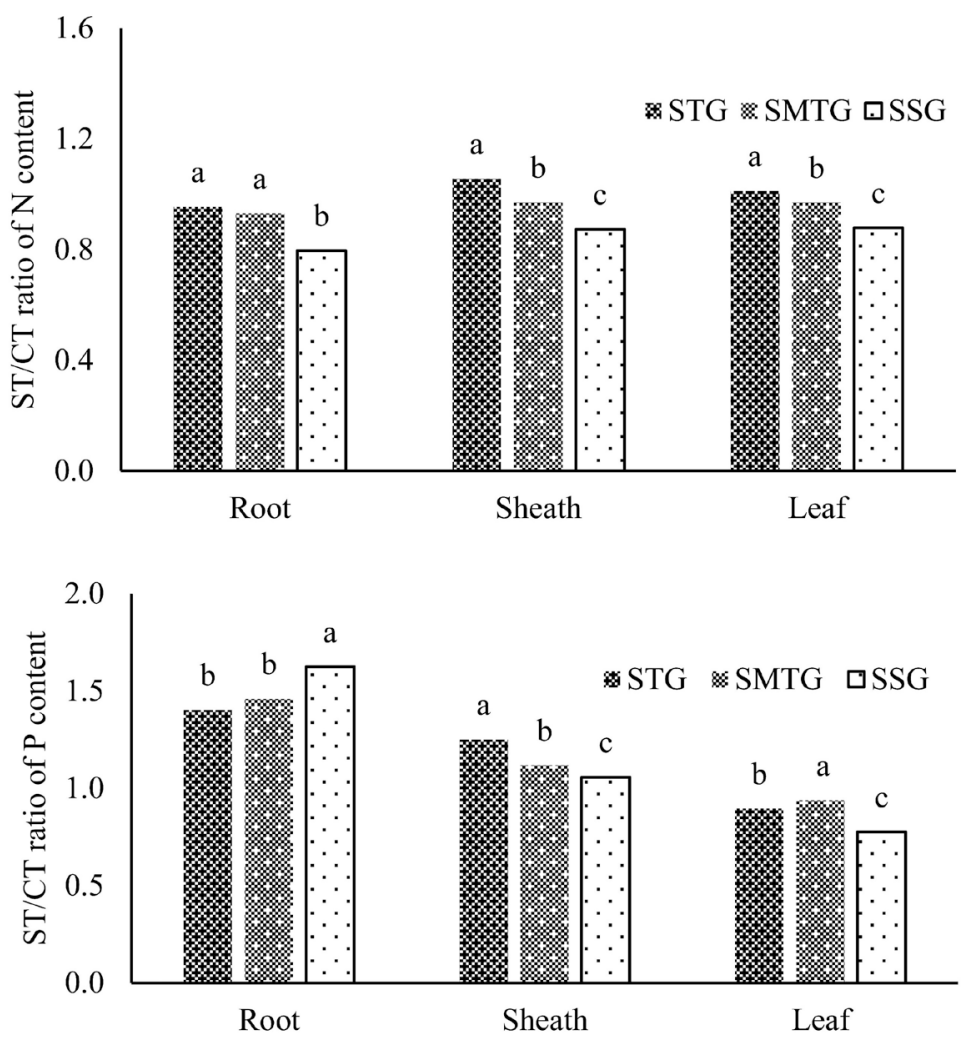

STG, salt-tolerant group; MSTG, moderately salt-tolerant group; SSG, salt-susceptible group; the histograms in the same parameter with the same letter are not significantly different by the Tukey HSD test $(P<0.05)$.

Figure 2. Salt stress treatment/control treatment (ST/CT) ratios of $\mathrm{N}$ and $\mathrm{P}$ contents in roots, sheaths, and leaves in the three salt tolerance groups. 

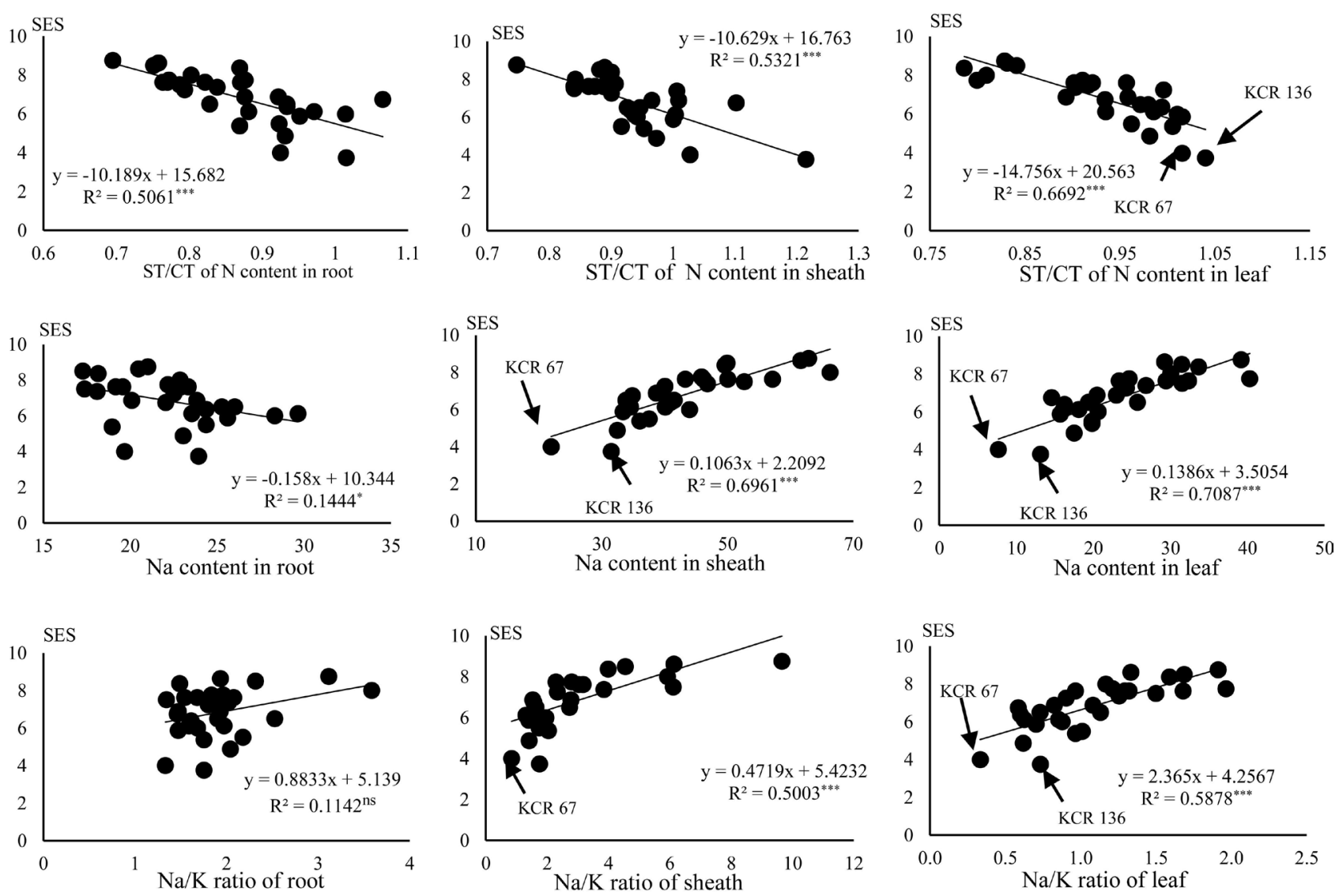

SES, standard evaluation score; ST/CT, salt stress treatment/control treatment; ns, no significance; ${ }^{*}, P<0.05$; ${ }^{* *}, P<0.001$.

Figure 3. Single regression analysis between SES and ST/CT ratios of $\mathrm{N}$ content, $\mathrm{Na} / \mathrm{K}$ ratios and $\mathrm{Na}$ contents in roots, sheaths, and leaves in the salt-stress treatment.

and leaves, and the $\mathrm{Na} / \mathrm{K}$ ratio in sheaths and leaves under the salt stress condition.

\subsection{Effects of Salt Stress on Mineral Contents in Roots, Sheaths, and Leaves}

We measured $\mathrm{Na}, \mathrm{K}, \mathrm{Mg}$, and Ca contents in roots, sheaths, and leaves for all 29 varieties (Table 2), and means were calculated for each salt tolerance group. The results are shown in Figure 4 and Figure 5. In the control treatment, differences in mineral contents among the three groups in all parts were not clear, except for root $\mathrm{K}$ content. The STG had the lowest $\mathrm{K}$ content in roots under the control condition. Interestingly, in the salt stress treatment, clear differences in mineral contents among the three groups were not seen in roots. The significant differences were in $\mathrm{Na}$ and $\mathrm{Mg}$ contents of leaves and $\mathrm{Na}, \mathrm{Mg}$, and $\mathrm{Ca}$ contents of sheaths.

\section{Na content}

The differences in $\mathrm{Na}$ content in sheaths and leaves among the three salt tolerance groups under the salt stress treatment were significant. $\mathrm{Na}$ content ranged from 17.26 (KCR246) to $29.64 \mathrm{mg} \mathrm{g}^{-1} \mathrm{DW}$ (KCR91) in roots, 21.99 (KCR67) to $66.28 \mathrm{mg} \cdot \mathrm{g}^{-1} \mathrm{DW}$ (KCR233) in sheaths, and 7.71 (KCR67) to 40.03 


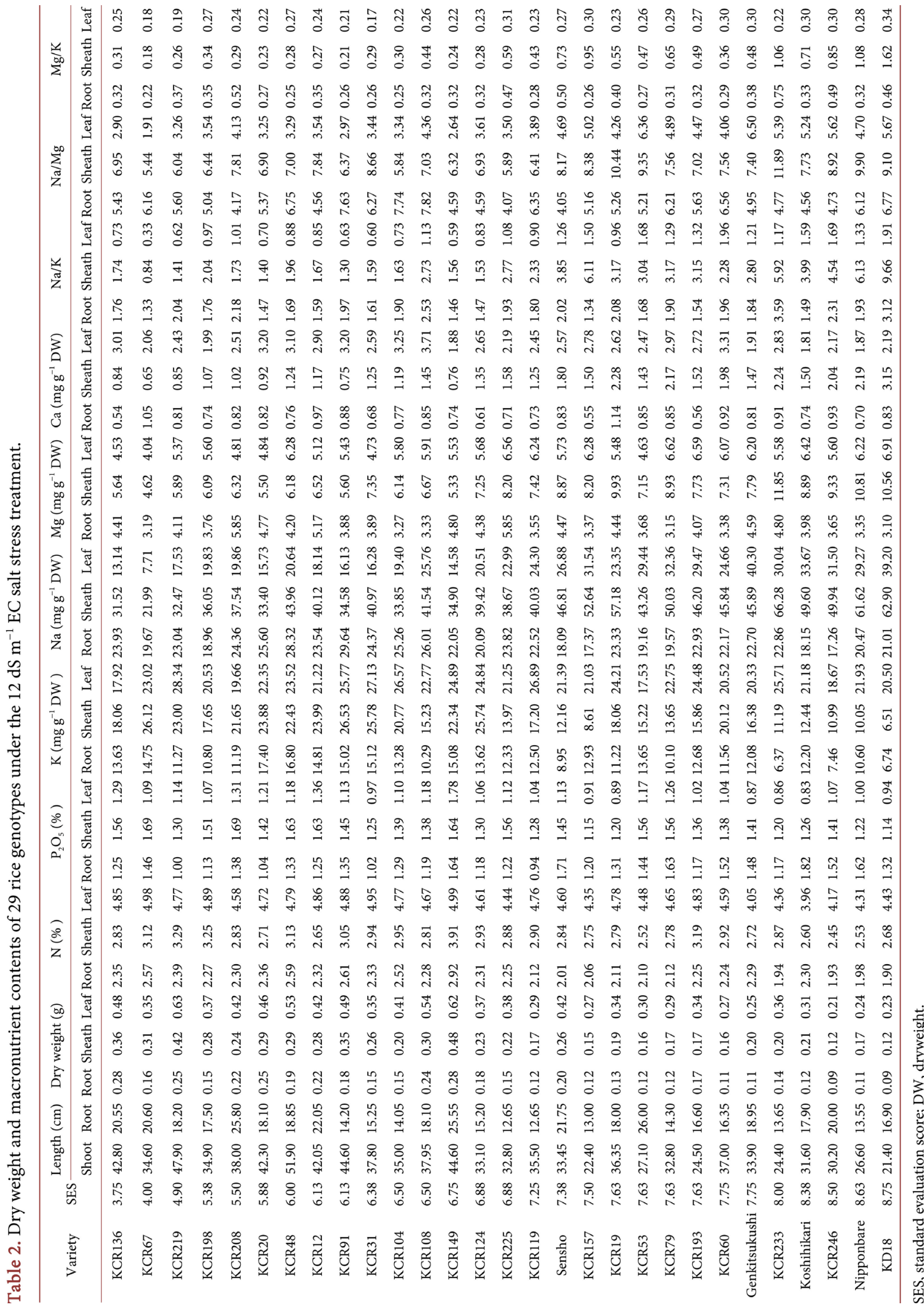



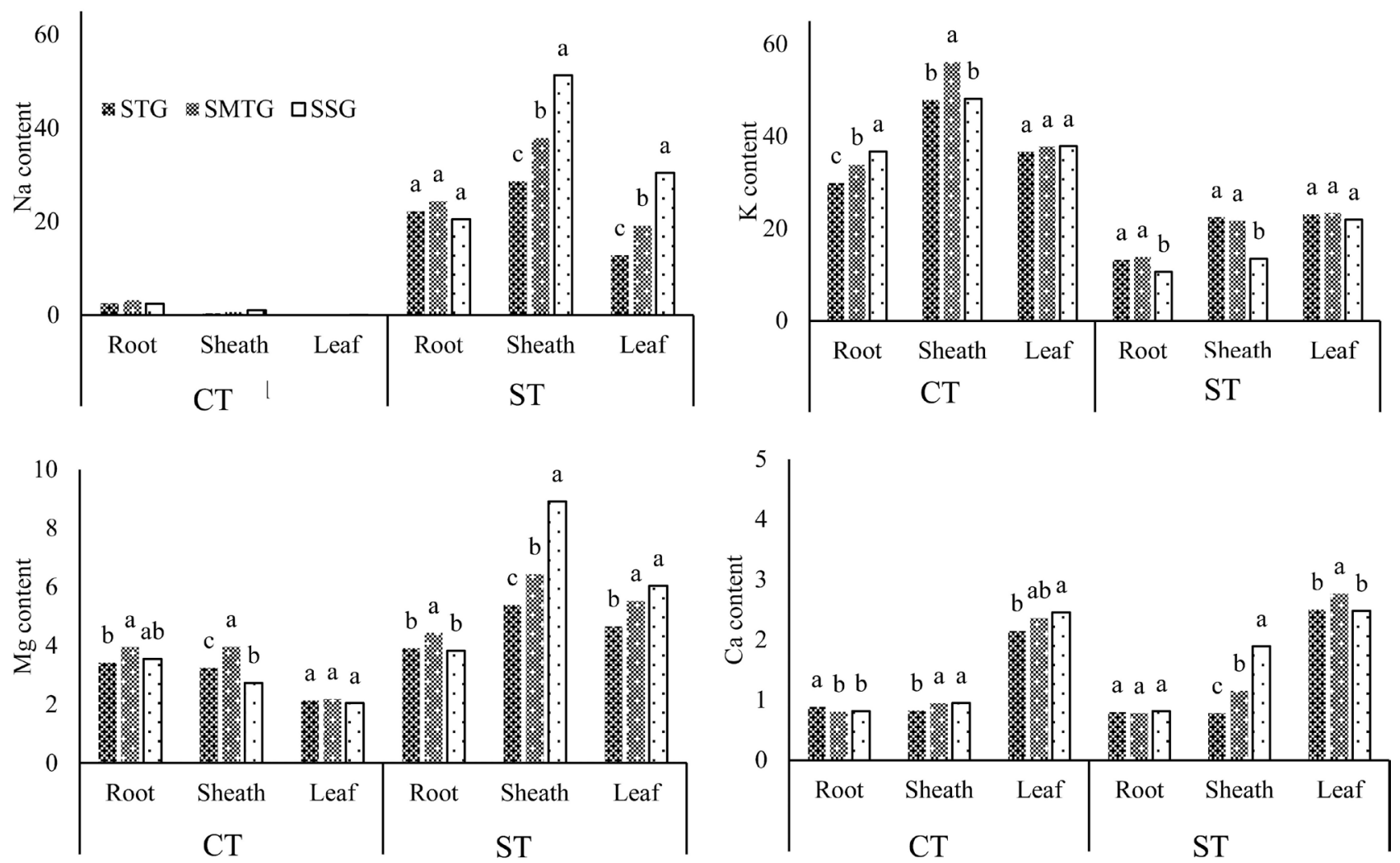

CT, control treatment; ST, salt stress treatment; DW, dry weight; STG, salt-tolerant group; MSTG, moderately salt-tolerant group; SSG, salt-susceptible group; the histograms in the same parameter with the same letter are not significantly different by the Tukey HSD test $(P<0.05)$.

Figure 4. Differences in mineral contents $\left(\mathrm{mg} \mathrm{g}^{-1} \mathrm{DW}\right)$ in roots, sheaths, and leaves among the three salt tolerance groups in the control and salt stress treatments.
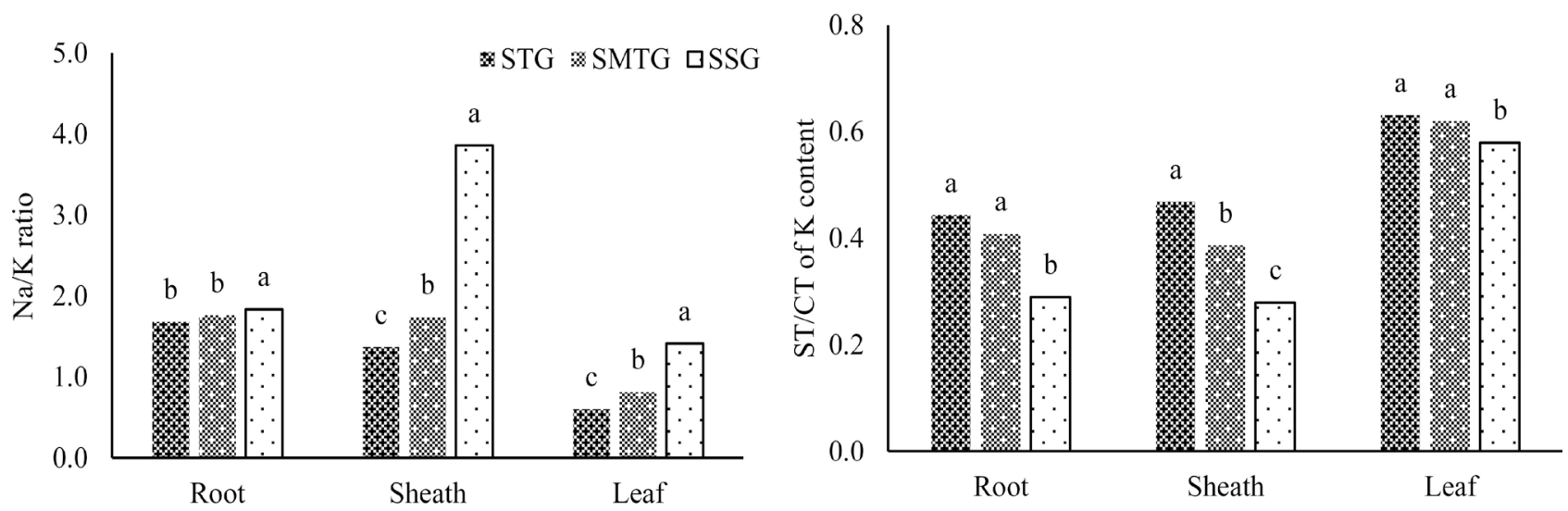

STG, salt-tolerant group; MSTG, moderately salt-tolerant group; SSG, salt-susceptible group; the histograms in the same parameter with the same letter are not significantly different by the Tukey HSD test $(P<0.05)$.

Figure 5. $\mathrm{Na} / \mathrm{K}$ ratio and ST/CT ratio for $\mathrm{K}$ content in roots, sheaths, and leaves in the three salt tolerance groups.

$\mathrm{mg} \cdot \mathrm{g}^{-1} \mathrm{DW}$ (Genkitsukushi) in leaves. The STG had the lowest Na contents among the three groups in sheaths and leaves $\left(28.66\right.$ and $12.79 \mathrm{mg} \cdot \mathrm{g}^{-1} \mathrm{DW}$, respectively). There were no differences in root $\mathrm{Na}$ content among the three salt tolerance groups. These results revealed that salt-tolerant varieties maintained good growth under salt stress condition by accumulating low amounts of $\mathrm{Na}^{+}$ 
ion in sheaths and leaves.

\section{$K$ content}

The differences in $\mathrm{K}$ content in roots, sheaths, and leaves among the three salt tolerance groups are shown in Figure 4. In the control treatment, there were significant differences in roots, but there were no clear differences in sheaths and leaves. The STG showed the lowest $\mathrm{K}$ content in roots. In the salt stress treatment, the STG had the highest K contents among the groups in all the three tissues. However, there were no significant differences in $\mathrm{K}$ content in leaves among the salt tolerance groups in either the control or the salt stress treatment condition. K content in roots ranged from 24.55 (KCR219) to $42.24 \mathrm{mg} \cdot \mathrm{g}^{-1} \mathrm{DW}$ (KCR119) in the control treatment and from 6.37 (KCR233) to $17.40 \mathrm{mg} \cdot \mathrm{g}^{-1} \mathrm{DW}$ (KCR20) in the salt stress treatment. The K content in sheaths ranged from 30.95 (KCR233) to $63.99 \mathrm{mg} \cdot \mathrm{g}^{-1} \mathrm{DW}$ (KCR91) in the control treatment and from 6.51 (KD18) to $26.53 \mathrm{mg} \cdot \mathrm{g}^{-1} \mathrm{DW}$ (KCR91) in the salt stress treatment. The K content in leaves ranged from 32.39 (KCR136) to $47.31 \mathrm{mg} \cdot \mathrm{g}^{-1} \mathrm{DW}$ (KCR233) in the control treatment and from 17.53 (KCR193) to $28.34 \mathrm{mg} \cdot \mathrm{g}^{-1} \mathrm{DW}$ (KCR91) in the salt stress treatment.

The ST/CT ratios for K content were calculated to discern how the $\mathrm{K}$ contents decreased when rice was cultivated under the salt stress condition (Figure 5). A significant difference was observed in the sheath ST/CT ratio for $\mathrm{K}$ content. The STG showed the highest ST/CT values for K content in all of the three parts, roots, sheaths, and leaves. This result indicated that the salt-tolerant varieties maintained $\mathrm{K}$ in the sheath under the salt stress condition, but that the salt-susceptible varieties exhibited $\mathrm{K}$ ion loss.

\section{$\mathrm{Na} /$ K ratio}

The ratios of $\mathrm{Na} / \mathrm{K}$ and $\mathrm{K} / \mathrm{Na}$ have been used in many studies of salt tolerance. If a plant can maintain low $\mathrm{Na} / \mathrm{K}$, or high $\mathrm{K} / \mathrm{Na}$, it may be tolerant to salt stress. Figure 5 shows that significant differences among the three groups were observed in sheaths and leaves. The $\mathrm{Na} / \mathrm{K}$ ratios in roots, sheaths, and leaves of the STG were lower than those of the other groups.

\section{$M g$ and Ca contents}

Under the control condition, clear differences in $\mathrm{Mg}$ and $\mathrm{Ca}$ contents were not seen among the three groups in roots, sheaths, or leaves. Under the salt stress condition, significant differences in $\mathrm{Mg}$ content were not observed in roots, but significant differences were observed in sheaths and leaves. The STG showed significantly lower $\mathrm{Mg}$ content in sheaths and leaves than the other groups. The result of the Pearson correlation analysis (Table S1) showed that SES had high correlation with $\mathrm{Mg}$ content in sheaths and leaves (PCI: 0.81 and 0.67, respectively). A significant difference in $\mathrm{Ca}$ content was not observed in roots or leaves, but a significant difference was observed in sheaths. The STG showed significantly lower Ca content in sheaths than the other groups. The result of the Pearson correlation analysis showed that SES scores were highly correlated with Ca content in sheaths (PCI: 0.79). 


\subsection{Multiple Regression Analysis of Na against $\mathrm{K}$, Mg, and Ca under Salt Stress Treatment}

The results of the multiple regression analysis are presented in Table 3 . The data show that the contents of $\mathrm{K}, \mathrm{Mg}$, and $\mathrm{Ca}$ were highly and significantly related to $\mathrm{Na}$ content in sheaths and leaves, but not in roots. The $\mathrm{R}^{2}$ values of the regression in sheaths, leaves, and roots were $0.90,0.64$, and 0.26 , respectively. Sheath $\mathrm{Mg}$ content and leaf $\mathrm{Mg}$ content had significant positive relations with sheath $\mathrm{Na}$ content and leaf $\mathrm{Na}$ content, respectively. Leaf $\mathrm{K}$ content had a significant negative relationship with leaf $\mathrm{Na}$ content.

\subsection{Effect of Stress Condition on Plant Dry Weight}

The reduction in dry weight (DW) of each variety is shown in Figure S1. The percent root DW reduction ranged from $42.11 \%$ (KCR208) to $75.93 \%$ (KCR 19), the percent sheath DW reduction ranged from 12.86\% (KCR67) to $70.54 \%$ (KCR 19 ), and the percent leaf DW reduction ranged from $35.71 \%$ (KCR104) to $68.54 \%$ (KCR 19). Plant growth was significantly affected under the salt stress condition, but the STG had the smallest decrease in DW. Significant differences in the salt stress treatment/control treatment (ST/CT) ratios of root, sheath, and leaf dry weight (DW) were observed among the three groups with different levels of salt tolerance (Figure 6). The ST/CT ratios of root, sheath, and leaf DW

Table 3. Multiple regression analysis of $\mathrm{Na}$ content against $\mathrm{K}, \mathrm{Mg}$, and Ca contents $\left(\mathrm{mg} \cdot \mathrm{g}^{-1} \mathrm{DW}\right)$ under the salt stress treatment.

\begin{tabular}{cccccccccccc}
\hline \multirow{2}{*}{$\mathrm{Na}$} & $\mathrm{K}$ & \multicolumn{2}{c}{$\mathrm{Mg}$} & \multicolumn{2}{c}{$\mathrm{Ca}$} & & \multicolumn{2}{c}{ Intercept } & \multicolumn{2}{c}{ Regression } \\
\cline { 2 - 11 } & Coefficients (C') & $P$-value & Coefficients (C') & $P$-value & Coefficients (C'”) & $P$-value & Intercept & $P$-value & $\mathrm{R}^{2}$ & $P$-value \\
\hline Root & 0.507 & $<0.05$ & 0.866 & $\mathrm{~ns}$ & 3.436 & $\mathrm{~ns}$ & 9.812 & $\mathrm{~ns}$ & 0.266 & $<0.05$ \\
Sheath & -0.051 & $\mathrm{~ns}$ & 4.071 & $<0.001$ & 3.921 & $\mathrm{~ns}$ & 7.957 & $\mathrm{~ns}$ & 0.903 & $<0.001$ \\
Leaf & -0.954 & $<0.01$ & 7.847 & $<0.001$ & -1.762 & $\mathrm{~ns}$ & 5.440 & $\mathrm{~ns}$ & 0.641 & $<0.001$ \\
\hline
\end{tabular}

DW, dry weight; $\mathrm{Na}\left(\mathrm{mg} \cdot \mathrm{g}^{-1} \mathrm{DW}\right)=\mathrm{C} \times \mathrm{K}+\mathrm{C}$ 'x $\mathrm{Mg}+\mathrm{C}^{\prime \prime} \mathrm{x} \mathrm{Ca}+$ Intercept.

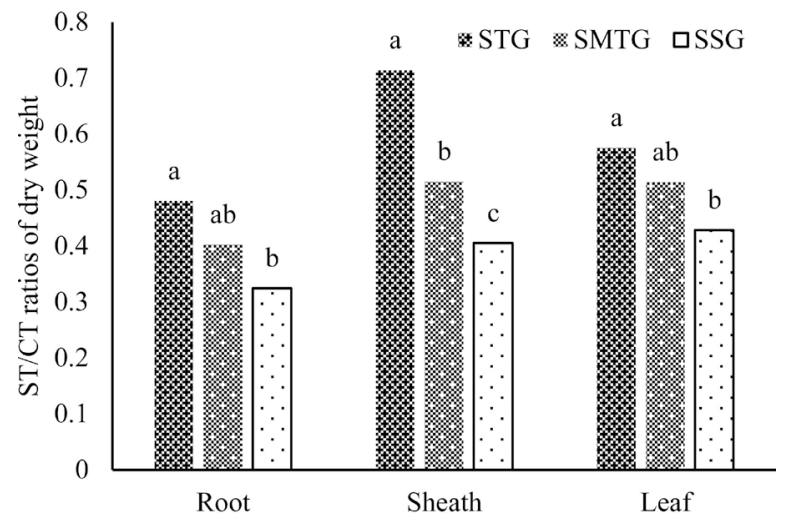

STG, salt-tolerant group; MSTG, moderately salt-tolerant group; SSG, salt-susceptible group; the histograms in the same parameter with the same letter are not significantly different by Tukey HSD test $(P<0.05)$

Figure 6. Salt stress treatment/control treatment (ST/CT) ratios of root, sheath, and leaf dry weight among the three salt tolerance groups. 
were highest in the STG, followed by the SMTG and SSG, respectively. The ST/CT ratio of the sheath DW of the STG was significantly higher than those of the MSTG and SSG. The STG had the highest root, sheath, and leaf DWs of 0.26 $\mathrm{g}, 0.39 \mathrm{~g}$, and $0.55 \mathrm{~g}$, and the SSG had the lowest DWs of $0.12 \mathrm{~g}, 0.17 \mathrm{~g}$, and 0.29 $\mathrm{g}$, respectively. The ST/CT ratios of the DW of root, sheath, and leaf of the STG were $0.48,0.71$, and 0.57 , respectively, the highest values among the groups.

\section{Discussion}

\subsection{Better Growth of Salt-Tolerant Varieties under Salt Stress}

Rice plants are very susceptible to salinity during the seedling stage [22] [23]. In this study, the results of the Pearson correlation analysis showed high correlations between dry matter and SES in roots, sheaths, and leaves. The PCI values were $-0.70,-0.72$, and -0.61 , respectively (Table $\mathrm{S} 1$ ). In addition, we calculated the reduction in DW and the ST/CT ratios for DW to evaluate how salt stress affected rice growth. The results showed that decrease in DW was lowest in sheaths. The STG had the highest ST/CT ratio for DW. These results indicate that the salt-tolerant varieties could maintain their growth and minimize the influences of the salt stress treatment. In particular, the limited decreases in dry matter of leaves and sheaths can be recognized in salt-tolerant varieties.

\subsection{Salt Tolerance and N Content in Roots, Sheaths, and Leaves}

$\mathrm{N}$ is the most important nutrient for rice [17]. A shortage of $\mathrm{N}$ leads to a decrease in leaf area [24], chlorophyll content, leaf photosynthesis, and biomass production [25], as well as reductions in yield and quality [26]. In this study, under the salt stress condition, the STG had the highest values for N content in roots, sheaths, and leaves. In addition, the STG had the highest ST/CT ratios for $\mathrm{N}$ content, indicating that the $\mathrm{N}$ content of STG varieties was less affected by salt stress. The ST/CT ratios for N content in the STG in sheaths and leaves were 1.07 and 1.01, respectively. Therefore, these varieties maintained better plant growth. Moreover, the high correlations between N content and SES (PCI of roots, sheaths, and leaves: $-0.61,-0.43$, and -0.67 , respectively) and between ST/CT ratios for $\mathrm{N}$ content and SES scores revealed that $\mathrm{N}$ content is useful for identifying a rice variety that is tolerant to salt stress.

\subsection{Mineral Contents in Different Parts of Seedlings and Salt Tolerance in Rice}

The analysis of the macronutrient contents of roots, sheaths, and leaves provided detailed insight into the allocation of macronutrients in rice favorable for salt stress tolerance. For example, the salt-tolerant varieties had low $\mathrm{Na}$ contents in sheaths and leaves, whereas the sensitive cultivars had high $\mathrm{Na}$ contents in sheaths and leaves [15]. In this study, as in previous studies, the Na contents observed in response to the salt stress treatment indicate that salt-tolerant varieties can be distinguished from other varieties by low $\mathrm{Na}$ content in sheaths and 
leaves. The absence of a significant difference in $\mathrm{Na}$ content in roots among the three salt tolerance groups suggests that salt stress toxicity may be due to $\mathrm{Na}$ accumulation in sheaths and leaves. [27] Lin et al. (2004) discussed the possibility that shoot $\mathrm{Na}$ accumulation causes salt stress toxicity in rice. [28] Munns and Tester (2008) reported that the most significant plant adaptation to salinity is the ability to restrict the transportation of $\mathrm{Na}$ to leaves and its accumulation in leaves. Our results are also in agreement with the suggestion of El-Hendawy et al. (2009) [29] from a study of wheat that low Na content in leaves is a good indicator for use in salt tolerance screening. The high correlations between SES scores and $\mathrm{Na}$ content in leaves and sheaths indicate that these $\mathrm{Na}$ contents can be recommended as a useful trait, with the advantage of easy sampling, for further studies of salt tolerance.

The role of $\mathrm{K}$ in osmotic regulation and its competitive effect with $\mathrm{Na}$ are very important factors for overcoming the salt stress condition [11]. Na ion is known to be the most harmful element to plants, and $\mathrm{K}$ ion is essential for reducing the uptake of $\mathrm{Na}$ [30]. Thus, $\mathrm{K}$ and $\mathrm{Na}$ contents and the balance of these ions play important roles in salt tolerance in rice. The maintenance of a low $\mathrm{Na} / \mathrm{K}$ ratio has been observed in salt-tolerant varieties, such as Pokkali, FL478, and IR 651. Shabala \& Cuin (2008) [31] reported that the intracellular K/Na ratio is the key determinant of salt tolerance. In this study, significant differences in the $\mathrm{Na} / \mathrm{K}$ ratio among the three salt tolerance groups were observed in sheaths and leaves. Moreover, SES was highly correlated with the $\mathrm{Na} / \mathrm{K}$ ratios of sheaths and leaves, but not of roots, suggesting that the $\mathrm{Na} / \mathrm{K}$ ratio should also be used for identifying salt-tolerant varieties.

Thu et al. (2017) [15] reported that the K contents among the four salt tolerance groups of rice differed in sheaths but not in roots and leaves under both control and salt stress conditions. However, in this study, $\mathrm{K}$ content of root differed among the salt tolerance groups under the control condition. In addition, both experiments showed the same result that $\mathrm{K}$ content of leaf did not differ among salt-tolerant groups under both control and salt stress treatments. These results indicate that the difference in $\mathrm{K}$ content of root under the control condition and in $\mathrm{K}$ content of sheath under salt stress condition might have been determined by the mineral content in the basal stem and the age of the seedling.

The rate of $\mathrm{Mg}^{2+}$ uptake can be strongly depressed by other cations, such as $\mathrm{K}^{+}, \mathrm{NH}_{4}^{+}, \mathrm{Ca}^{2+}, \mathrm{Mn}^{2+}$, and $\mathrm{H}^{+}$[32]. The results of this study indicating that the differences in $\mathrm{Mg}$ content among salt tolerance groups were significant in sheaths are in agreement with the results of Thu et al. (2017) [15]. The salt-tolerant varieties exhibited the lowest $\mathrm{Mg}$ content when the rice was grown under the salt stress condition. This result contrasts with the result of Hussain (2003) [33] that $\mathrm{Mg}$ concentration in rice shoots was not significantly affected by salinity. In combination with the results of high correlation with SES, these results suggest that the Mg contents of sheaths and leaves might be used as an indicator of salt tolerance. 
$\mathrm{Mg}$ and $\mathrm{Ca}$ are necessary for plant growth. However, under the salt stress condition, the results showed that the STG had high $\mathrm{K}$ content and low Mg and Ca contents in sheaths and leaves; whereas the SSG had low K content in roots, sheaths, and leaves and high Mg and Ca contents in sheaths and leaves. This result indicates that salt-tolerant varieties prioritize selection of $\mathrm{K}$ ion to overcome the salt stress condition by depression of $\mathrm{Mg}$ and $\mathrm{Ca}$ ion uptake. Niazi et al. (1992) [34] reported that selective uptake of K seemed to be among the processes involved in tolerance of cultivars to salt stress.

In summary, under the salt stress condition, prominent features of the salt-tolerant group of rice were high ST/CT ratio for dry matter in sheath, high $\mathrm{N}$ content in sheaths and leaves, low $\mathrm{Na}$ content in sheaths and leaves, low $\mathrm{Mg}$ content in sheaths and leaves, low Ca content in sheaths, high ST/CT ratio for N content in sheaths and leaves, high ST/CT ratio for $\mathrm{K}$ content in sheaths, and low $\mathrm{Na} / \mathrm{K}$ ratio in sheaths and leaves. Interestingly, clear differences among the three salt tolerance groups were not seen in the mineral contents in roots, which was an indicator in several previous studies of salt tolerance [27] [35] [36].

\section{Conclusion}

The results showed that the allocation of macronutrient contents in different parts of the rice plant is important for tolerance to salt stress. The salt-tolerant varieties exhibited low $\mathrm{K}$ content in root (in the control condition), low SES scores, high $\mathrm{N}$ content in leaves and sheaths, low $\mathrm{Na}$ content in leaves and sheaths, low Mg content in leaves and sheaths, and low Ca content in sheaths (in the salt stress condition). The salt-tolerant varieties also showed high ST/CT ratios for dry matter in sheaths and leaves, high ST/CT ratios for $\mathrm{N}$ content in sheaths and leaves, high ST/CT ratios for $\mathrm{K}$ content in sheaths, and low $\mathrm{Na} / \mathrm{K}$ ratios in sheaths and leaves. Therefore, these parameters might be useful for further studies of salt tolerance in rice. The salt-tolerant cultivars, KCR136 and KCR67, were chosen for further study because they had low SES scores (3.8 and 4.0 , respectively), low $\mathrm{Na}$ content in sheaths (31.52 and $21.99 \mathrm{mg} \cdot \mathrm{g}^{-1} \mathrm{DW}$, respectively) and in leaves (13.14 and $7.71 \mathrm{mg} \cdot \mathrm{g}^{-1} \mathrm{DW}$, respectively), low $\mathrm{Mg}$ content in sheaths (5.64 and $4.62 \mathrm{mg} \cdot \mathrm{g}^{-1} \mathrm{DW}$, respectively) and in leaves (4.53 and $4.04 \mathrm{mg} \cdot \mathrm{g}^{-1} \mathrm{DW}$, respectively), low Ca content in sheaths $\left(0.84\right.$ and $0.65 \mathrm{mg} \cdot \mathrm{g}^{-1}$ $\mathrm{DW}$, respectively), and low $\mathrm{Na} / \mathrm{K}$ ratios in sheaths (1.74 and 0.84 , respectively) and in leaves ( 0.73 and 0.33 , respectively) under the salt stress condition.

\section{References}

[1] Szabolcs, I. and Pessarakli, M. (2010) Soil Salinity and Sodicity as Particular Plant/Crop Stress Factor. In: Pessarakli, M., Ed., Handbook of Plant and Crop Stress, 3rd Edition, Taylor \& Francis Publishing Group, Florida, 3-21.

[2] Kobayashi, N.I., Yamaji, N., Yamamoto, H., Okubo, K., Ueno, H., Costa, A., et al. (2017) OsHKT1;5 Mediates $\mathrm{Na}^{+}$Exclusion in the Vasculature to Protect Leaf Blades and Reproductive Tissues from Salt Toxicity in Rice. Plant Journal, 91, 657-670. https://doi.org/10.1111/tpj.13595 
[3] Maas, E.V. (1990) Crop Salt Tolerance. In: Tanji, K.K., Ed., Agricultural Salinity Assessment and Management, ASCE Manual Reports on Engineering Practices, Vol. 71, ASCE, New York, 262-304.

[4] Munns, R., James, R.A. and Läuchli, A. (2006) Approaches to Increasing the Salt Tolerance of Wheat and Other Cereals. Journal of Experimental Botany, 57, 1025-1043. https://doi.org/10.1093/jxb/erj100

[5] Asch, F., Dingkuhn, M., Dörffling, K. and Miezan, K. (2000) Leaf K/Na Ratio Predicts Salinity Induced Yield Loss in Irrigated Rice. Euphytica, 113, 109-118. https://doi.org/10.1023/A:1003981313160

[6] Negrão, S., Courtois, B., Ahmadi, N., Abreu, I., Saibo, N. and Oliveira, M.M. (2011) Recent Updates on Salinity Stress in Rice: From Physiological to Molecular Responses. Critical Reviews in Plant Sciences, 30, 329-377. https://doi.org/10.1080/07352689.2011.587725

[7] Flowers, T.J. (2004) Improving Crop Salt Tolerance. Journal of Experimental Botany, 55, 307-319. https://doi.org/10.1093/jxb/erh003

[8] Rengasamy, P. (2006) World Salinization with Emphasis on Australia. Journal of Experimental Botany, 57, 1017-1023. https://doi.org/10.1093/jxb/erj108

[9] Blumwald, E. and Grover, A. (2006) Salt Stress Response in Rice: Genetics, Molecular Biology, and Comparative Genomics. Plant Molecular Biology, 6, 263-284. https://doi.org/10.1007/s10142-006-0032-5

[10] Sahi, C., Singh, A., Kumar, K., Blumwald, E. and Grover, A. (2006) Salt Stress Response in Rice: Genetics, Molecular Biology, and Comparative Genomics. Functional \& Integrative Genomics, 6, 263-284. https://doi.org/10.1007/s10142-006-0032-5

[11] Alam, S.M. (1999) Nutrient Uptake by Plants under Stress Conditions. In: Pessarakli, M., Ed., Handbook of Plant and Crop Stress, Marcel Dekker, New York, 285-313.

[12] Tester, M. and Davenport, R. (2003) $\mathrm{Na}^{+}$Tolerance and $\mathrm{Na}^{+}$Transport in Higher Plants. Annals of Botany, 91, 503-527. https://doi.org/10.1093/aob/mcg058

[13] Flowers, T.J. and Yeo, A. (1995) Breeding for Salinity Resistance in Crop Plants: Where Next? Australian Journal of Plant Physiology, 22, 875-884. https://doi.org/10.1071/PP9950875

[14] Pitman, M.G. and Lauchli, A. (2002) Global Impact of Salinity and Agricultureeco Systems. In: Lauchi, A. and Luttge, U., Eds., Salinity: Environment-Plants-Molecules, Klwer, Dordecht, the Netherlands, 3-20.

[15] Thu, T.T.P., Yasui, H. and Yamakawa, T. (2017) Effects of Salt Stress on Plant Growth Characteristics and Mineral Content in Diverse Rice Genotypes. Soil Science and Plant Nutrition, 63, 264-273. https://doi.org/10.1080/00380768.2017.1323672

[16] Japan Meteorological Agency (2018) http://www.data.jma.go.jp/obd/stats/etrn/view/monthly_s1.php?prec_no=82\&block no $=47807$ \&year $=2016 \&$ month $=5 \&$ day $=$ \&view $=$ p 1

[17] Yoshida, S. (1981) Fundamentals of Rice Crop Science. The International Rice Research Institute, Los Banos, Laguna, Philippines, Manila, Philippines.

[18] Gregorio, G.B., Senadhira, D. and Mendoza, R.D. (1997) Screening Rice for Salinity Tolerance. IRRI Discussion Paper Series, 22, 30.

[19] Ohyama, T., Ito, M., Kobayashi, K., Araki, S., Yasuyoshi, S., Sasaki, O., Yamazaki, T., Soyama, K., Tanemura, R., Mizuno, Y. and Ikarashi, T. (1991) Analytical Proce- 
dures of $\mathrm{N}, \mathrm{P}, \mathrm{K}$ Contents in Plant and Manure Materials Using $\mathrm{H}_{2} \mathrm{SO}_{4} \mathrm{H}_{2} \mathrm{O}_{2}$ Kjeldahl Digestion Method. Bulletin of the Faculty of Agriculture, Niigata University, 43, 110-120.

[20] Cataldo, D.A., Schrader, L.E. and Youngs, V.L. (1974) Analysis by Digestion and Colorimetric Assay of Total Nitrogen in Plant Tissues High in Nitrate. Crop Science, 14, 854-856. https://doi.org/10.2135/cropsci1974.0011183X001400060024x

[21] Murphy, J. and Riley, J. (1962) A Modified Single Solution for the Determination of Phosphate in Natural Waters. Analytica Chimica Acta, 27, 31-36. https://doi.org/10.1016/S0003-2670(00)88444-5

[22] Pearson, G.A. and Bernstein, L. (1959) Salinity Effects at Several Growth Stages of Rice. Agrononomy Journal, 51, 654-657. https://doi.org/10.2134/agronj1959.00021962005100110007x

[23] Flowers, T.J. and Yeo, A.R. (1981) Variability in the Resistance of Sodium Chloride Salinity within Rice (Oryza sativa L.) Varieties. New Phytologist, 88, 363-373. https://doi.org/10.1111/j.1469-8137.1981.tb01731.x

[24] Fernandez, C.J., Mclnnes, K.J. and Cothren, J.T. (1996) Water Status and Leaf Area Production in Water- and Nitrogen-Stressed Cotton. Crop Science, 36, 1224-1233. https://doi.org/10.2135/cropsci1996.0011183X003600050026x

[25] Zhao, D. and Oosterhuis, D.M. (2000) Nitrogen Application Effect on Leaf Photosynthesis, Nonstructural Carbohydrate Concentrations and Yield of Field-Grown Cotton. In: Oosterhuis, D.M., Ed., AAES Special Report, Proceedings of the 2000 Arkansas Cotton Research, Arkansas Agricultural Experiment Station, University of Arkansas, Fayetteville, No. 198, 69-71.

[26] Yang, H., Yang, J., Lv, Y. and He, J. (2014) SPAD Values and Nitrogen Nutrition Index for the Evaluation of Rice Nitrogen Status. Plant Production Science, 17, 81-92. https://doi.org/10.1626/pps.17.81

[27] Lin, H.X., Zhu, M.Z., Yano, M., Gao, J.P., Liang, Z.W., Su, W.A., Chao, D.Y., et al. (2004) QTLs for $\mathrm{Na}^{+}$and $\mathrm{K}^{+}$Uptake of the Shoots and Roots Controlling Rice Salt Tolerance. Theoretical and Applied Genetics, 108, 253-260. https://doi.org/10.1007/s00122-003-1421-y

[28] Munns, R. and Tester, M. (2008) Mechanisms of Salinity Tolerance. Annual Review of Plant Biology, 59, 651-681. https://doi.org/10.1146/annurev.arplant.59.032607.092911

[29] El-Hendawy, S.E., Ruan, Y., Hu, Y. and Schmidhalter, U. (2009) A Comparison of Screening Criteria for Salt Tolerance in Wheat under Field and Controlled Environmental Conditions. Journal of Agronomy and Crop Science, 195, 356-367. https://doi.org/10.1111/j.1439-037X.2009.00372.x

[30] Wu, Y., Hu, E.Y. and Xu, E.G. (2009) Interactive Effects of Potassium and Sodium on Root Growth and Expression of K/Na Transporter Genes in Rice. Plant Growth Regulation, 57, 271-280. https://doi.org/10.1007/s10725-008-9345-9

[31] Shabala, S. and Cuin, T.A. (2008) Potassium Transport and Plant Salt Tolerance. Physiologia Plantarum, 133, 651-669. https://doi.org/10.1111/j.1399-3054.2007.01008.x

[32] Marschner, H. (1995) Mineral Nutrition of Higher Plants. Academic Press, London.

[33] Hussain, A., Ali, A., Sarwar, G., Mujeeb, F. and Tahir, M. (2003) Mechanism of Salt Tolerance in Rice. Pedosphere, 13, 233-238.

[34] Niazi, M.L.K., Mohmood, K., Mujtaba, S.M. and Malik, K.A. (1992) Salinity Tolerance in Different Cultivars of Barley (Hordium vulgare L.). Biology Plant, 34, 30. 
https://doi.org/10.1007/BF02923603

[35] De Leon, T.B., Linscombe, S., Gregorio, G. and Subudhi, P.K. (2015) Genetic Variation in Southern USA Rice Genotypes for Seedling Salinity Tolerance. Frontiers in Plant Science, 6, 374. https://doi.org/10.3389/fpls.2015.00374

[36] Thomson, M.J., Ocampo, M., Egdane, J., Rahman, M.A., Sajise, A.G., Adorada, D.L., Tumimbang-Raiz, E., Blumwald, E., Seraj, Z.I., Singh, R.K., Gregorio, G.B. and Ismail, A.M. (2010) Characterizing the Saltol Quantitative Trait Locus for Salinity Tolerance in Rice. Rice, 3, 148-160. https://doi.org/10.1007/s12284-010-9053-8 


\section{Appendix}

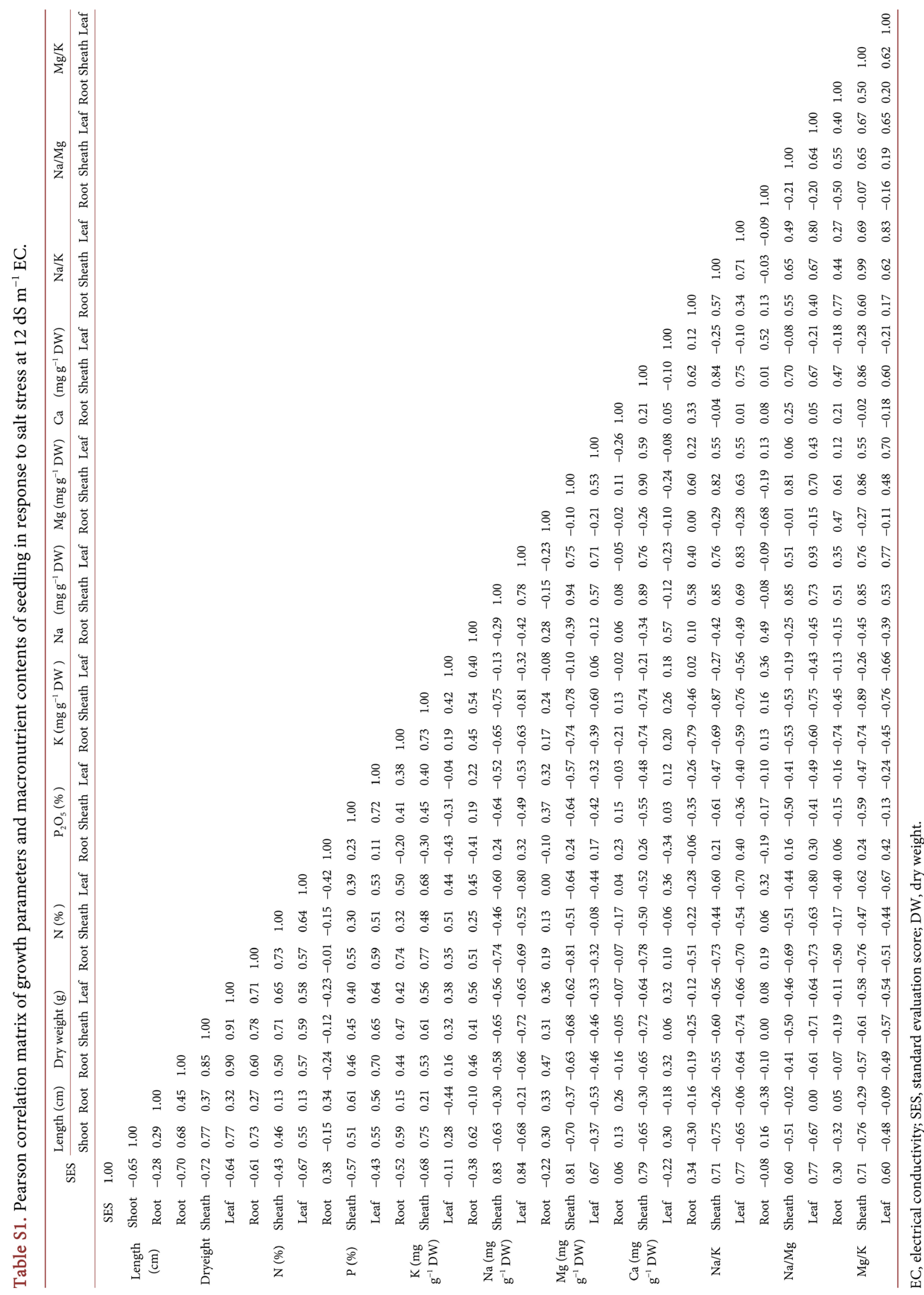



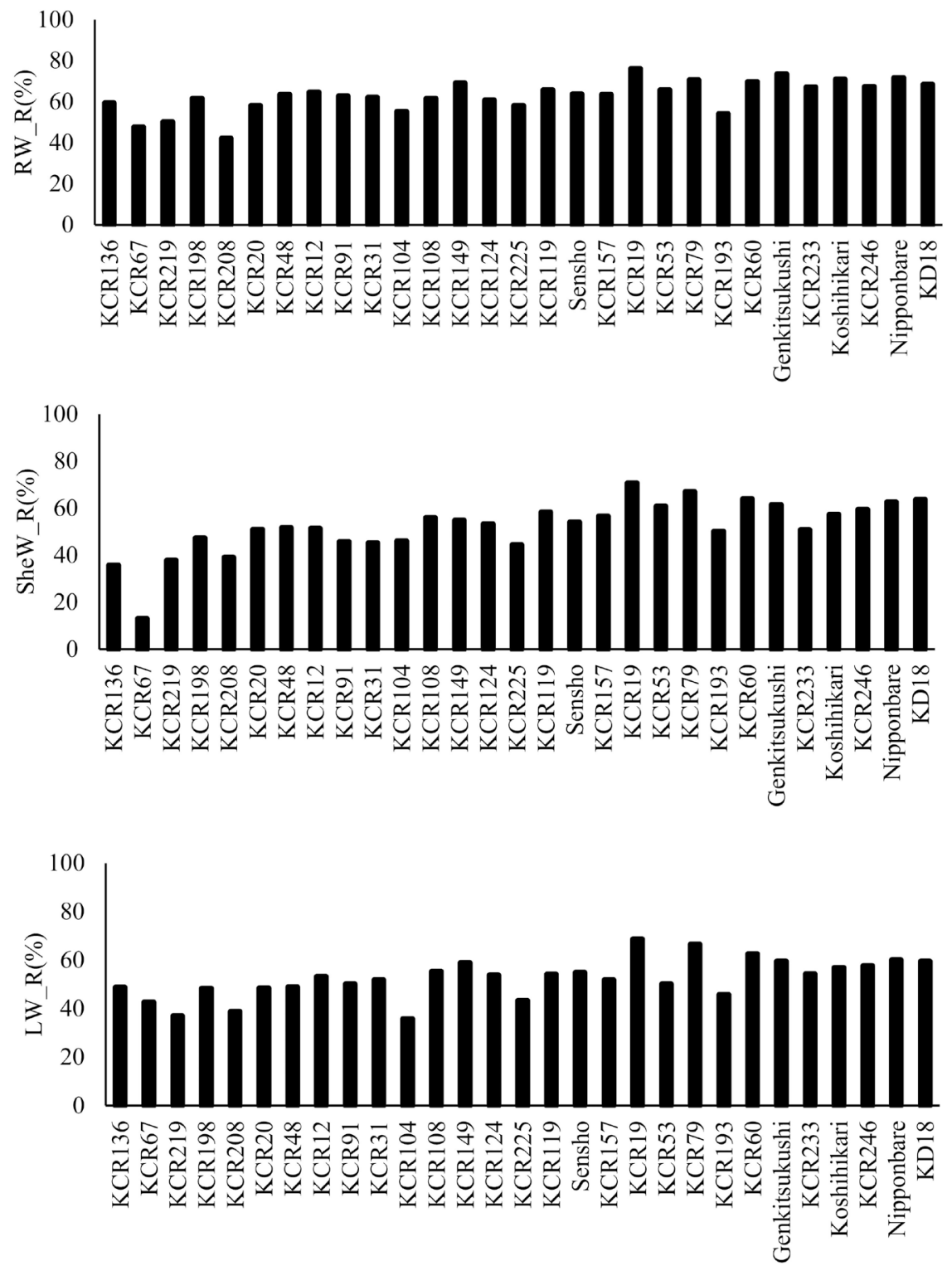

SES, Standard Evaluation Score; SheW_R, sheath dry weight reduction; LW_R, leaf dry weight reduction; RW_R, root dry weight reduction.

Figure S1. Reduction in dry matter of roots, sheaths, and leaves of 29 rice varieties under the salt stress condition. 